\title{
PENINGKATAN KEDISIPLIN SISWA MELALUI LAYANAN BIMBINGAN KELOMPOK: STUDI DI KELAS XI SMA NEGERI 1 MAUMERE
}

\author{
Martha Loran Retong \\ SMA Negeri 1 Maumere, Kab. Sikka, Nusa Tenggara Timur
}

Diterima 18 Maret 2018, disetuji 28 Maret 2019, diterbitkan 30 Oktober 2019

Pengutipan: Retong, M.L. (2019). Peningkatan Kedisiplin Siswa Melalui Layanan Bimbingan Kelompok: Studi di Kelas XI SMA Negeri 1 Maumere. Gema Wiralodra, Vol 10, No 1, Hal 155-166, April 2019

\begin{abstract}
ABSTRAK
Kedisplinan merupakan salah satu sikap yang harus dimiliki oleh siswa. Siswa yang memiliki kedisiplinan akan mempengaruhi keberhasilan di dalam menyelesaikan sekolah. Oleh karena itu, tujuan penelitian yakni untuk mendeskripsikan peningkatan kedisiplinan siswa melalui pelaksanaan layanan bimbingan kelompok. Metode yang digunakan dalam penelitian ini adalah metode deskriptif, dengan objeknya siswa kelas XI SMA Negeri 1 Mauemere. Subjek penelitian ini adalah guru BK dan alat pengumpul data yang digunakan yakni angket, observasi, wawancara serta dokumentasi. Hasil penelitian menunjukan bahwa penggunaan layanan bimbingan kelompok sangat efektif dalam upaya meningkatkan disiplin siswa yang berdampak pada peningkatan tingkat kehadiran siswa, tingkat disiplin siswa pada awal pelajaran/ masuk kelas, selama proses pembelajaran dan akhiri dari pembelajaran (pulang sesuai jadwal) pada kelas XI SMA Negeri 1 Maumere sangat tinggi, dan perilaku disiplin di dalam kelas dan disiplin menepati jadwal terus meningkat dari siklus 1 sampai siklus 2.
\end{abstract}

Kata Kunci: Disiplin siswa, layanan bimbingan kelompok

\section{ABSTRACT}

Discipline is one of the attitudes that must be possessed by students. Students who have discipline will affect success in completing school. Therefore, the research objective is to describe the improvement of student discipline through the implementation of group guidance services. The method used in this research is the descriptive method, with the object of class XI students of SMA Negeri 1 Mauemere. The subject of this research was the BK teacher and the data collection tools used were questionnaires, observation, interview, and documentation. The results showed that the use of group counseling services was very effective in efforts to improve student discipline which had an impact on increasing the level of student attendance, the level of student discipline at the beginning of the lesson / entering class, during the learning process and ending of learning (returning on schedule) in class XI of SMA Negeri 1 Maumere is very high, and disciplinary behavior in the classroom and discipline keep the schedule continues to increase from cycle 1 to cycle 2.

Keywords: Student discipline, group guidance services

\section{PENDAHULUAN}

Masalah disiplin merupakan masalah yang dihadapi sekolah-sekolah dewasa Ini (Wahyuni, Wati \& Ely, 2016). Disiplin membantu siswa dalam proses pembentukan sikap, prilaku dan akan mengantar seorang siswa sukses dalam belajar dan ketika bekerja nanti 
(Ariananda, Hasan\& Rakhman, 2014). Didalam proses balajar mengajar, disiplin terhadap tata tertib sangat penting untuk diterapkan, karena jika dalam suatu sekolah tidak memiliki tata tertib maka proses belajar mengajar tidak akan berjalan dengan lancar sesuai dengan rencana Haryono (2016). Pembinaan disiplin dan perilaku merupakan kegiatan yang dilakukan secara terus menerus dalam kehidupan siswa sehari-hari di sekolah, sehingga diharapkan menjadi kebiasaan yang baik (Rohman, 2018).

Arikunto (1990:137) membagi tiga macam indikator kedisiplinan, yaitu: 1) perilaku kedisiplinan di dalam kelas, 2) perilaku kedisiplinan di luar kelas di lingkungan sekolah, dan 3) perilaku kedisiplinan di rumah. Tu'u (2004:91) dalam penelitian mengenai disiplin sekolah mengemukakan bahwa indikator yang menunjukkan pergeseran atau perubahan hasil belajar siswa sebagai kontribusi mengikuti dan menaati peraturan sekolah adalah meliputi: dapat mengatur waktu belajar di rumah, rajin dan teratur belajar, perhatian yang baik saat belajar di kelas, dan ketertiban diri saat belajar di kelas. Sedangkan Nurdin (2005:80) membagi indikator disiplin belajar menjadi empat macam, yaitu:1) ketaatan terhadap waktu belajar, 2) ketaatan terhadap tugas-tugas pelajaran, 3) ketaatan terhadap penggunaan fasilitas belajar, dan 4) ketaatan menggunakan waktu datang dan pulang.

Walaupun kedisiplinan faktor penting dalam indicator keberhasilan sekolah, namun berdasarkan pengalaman peneliti selama bertahun-tahun sebagai guru BK di SMA Negeri 1 Maumere, guru yang mengajar kelas XI IPS sering kali menghadapi masalah tentang rendahnya disiplin siswa yang berdampak pula pada rendahnya disiplin siswa, kehadiran siswa, kedisiplinan, nilai, keaktifan siswa selama proses belajar mengajar. Indikasi bahwa rendahnya disiplin siswa adalah berdasarkan hasil pengamatan awal yang peneliti lakukan pada siswa kelas XI IPS di awal semester genap tahun pelajaran 2018/2019 dan berdasarkan informasi dari guru mata pelajaran. Berdasarkan hasil pengamatan ditemukan sejumlah siswa yang sering kali melakukan pelanggaran terhadap tata tertib sekolah, yaitu dalam hal terlambat datang ke sekolah, sering keluar kelas pada saat pelajaran berlangsung, tidak masuk sekolah tanpa keterangan, bahkan ditemukan siswa yang membuat surat izin sendiri dengan meniru tanda tangan orang tuanya.

Salah satu cara untuk membuat siswa disiplin yakni program layanan bimbingan kelompok. Prayitno (2004:4) mengemukakan bahwa bimbingan kelompok adalah suatu kegiatan yang dilakukan oleh sekelompok orang dengan memanfaatkan dinamika kelompok. Artinya, semua peserta dalam kegiatan kelompok saling berinteraksi, bebas mengeluarkan pendapat, menanggapi, memberi saran, dan lain-lain sebagainya; apa 
yang dibicarakan itu semuanya bermanfaat untuk diri peserta yang bersangkutan sendiri dan untuk peserta lainnya. Prayitno (2004:4) menjelaskan bahwa dalam komponen bimbingan kelompok yaitu pemimpin kelompok, anggota kelompok, dan dinamika kelompok. Di bawah ini akan diuraikan secara singkat komponen bimbingan kelompok yaitu: Pertama pemimpin kelompok (PK), adalah konselor yang terlatih dan berwenang menyelenggarakan praktik konseling professional. Sebagaimana jenis layanan konseling lainnya, konselor memiliki keterampilan khusus menyelenggarakan bimbingan kelompok secara khusus, PK diwajibkan menghidupkan dinamika kelompok antara semua peserta yang mengarah kepada pencapaian tujuan- tujuan umum dalam bimbingan kelompok. Kedua anggota kelompok, tidak semua kumpulan atau individu dapat dijadikan anggota bimbingan kelompok. Untuk terselenggaranya bimbingan kelompok seorang konselor harus membentuk kumpulan individu menjadi sebuah kelompok yang memiliki sebuah persyaratan sebagaimana tersebut di atas. Besarnya kelompok (jumlah anggota kelompok) dan homogenitas atau heterogenitas anggota kelompok dapat dipengaruhi kinerja kelompok. Sebaiknya jumlah kelompok tidak terlalu besar dan tidak terlalu kecil. Kekurangefektifan kelompok akan terasa jika jumlah kelompok melebihi sepuluh orang. Ketiga dinamika kelompok, merupakan sinergi dari semua faktor yang ada di dalam suatu kelompok. Artinya merupakan pengarahan secara serentak semua faktor yang dapat digerakkan dalam kelompok itu. Dengan demikian dinamika kelompok merupakan jiwa yang menghidupkan dan menghidupi suatu kelompok, dinamika kelompok ini dimanfaatkan untuk mencapai tujuan bimbingan kelompok.

Prayitno (1995:14) mengemukakan secara khusus dinamika kelompok dapat dimanfaatkan untuk memecahkan masalah pribadi para anggota kelompok, yaitu apabila interaksi dalam kelompok difokuskan pada pemecahan masalah pribadi yang dimaksudkan. Dalam suasana seperti ini melalui dinamika kelompok yang berkembang masing-masing anggota kelompok akan menyumbang baik secara langsung maupun tidak langsung dalam pemecahan masalah pribadi tersebut. Dinamika kelompok akan benarbenar berjalan dengan baik apabila kelompok tersebut hidup mengarah pada tujuan yang ingin dicapai dan bermanfaat bagi masing-masing anggota kelompok serta ditentukan oleh peranan anggota kelompok.

Berdasarkan hal itu, maka penelitian ini bertujuan untuk untuk mendeskripsikan peningkatan kedisiplinan siswa melalui pelaksanaan layanan bimbingan kelompok di SMA Negeri 1 Maumere, Nusa Tenggara Timur. 


\section{METODELOGI PENELITIAN}

Subjek penelitian ini adalah seluruh siswa kelas XI IPS SMA Negeri 1 Maumere yang berjumlah 35 Orang, 15 orang laki-laki dan 20 orang perempuan. Objek penelitian adalah perilaku pelanggaran kedisplinan oleh siswa. Prosedur dalam penelitian tindakan bimbingan konseling (Action Reseach In Counseling) yaitu : (1) Dari 35 orang siswa kelas XI IPS yang menjadi pokus dalam penelitian ini adalah 10 orang siswa yang sering mengalami pelanggaran/maslah yang sama/general dalam disiplin siswa. (2) Penentuan jumlah 10 orang siswa berdasarkan pengamatan awal, masukan dari guru dan wali kelas.

Pelaksanaan penelitian tindakan bimbingan konseling (Action Reseach In Counseling), dilakukan dalam 3 siklus setiap siklusnya terdiri dari perencanaan layanan bimbingan kelompok, pelaksanaan layanan bimbingan kelompok, hasil pelaksanaan layanan bimbingan kelompok dan refleksi hasil pelaksanaan layanan bimbingan kelompok. Adapun tahapannya sebagai berikut:

1. Perencanaan layanan bimbingan kelompok

2. Menyusun Rencana Pelaksanaan Layanan (RPL)

3. Mengumpulkan 10 orang siswa kelas XI IPS yang menjadi sasaran penelitian yang sering melanggran disiplin.

4. Pelaksanaan layanan bimbingan kelompok

5. Konselor menyampaikan tujuan dan manfaat kegiatan layanan

6. Saling memperkenalkan dan mengungkapkan diri anggota kelompok

7. Masing-masing anggota secara bebas mengemukakan masalah dan membahasnya secara mendalam dan tuntas.

8. Melakukan observasi terhadap siswa yang telah diberikan layanan bimbingan kelompok.

9. Hasil pelaksanaan layanan bimbingan kelompok.

10. Melakukan analisis hasil observasi terhadap siswa yang telah diberikan layanan bimbingan kelompok

11. Memberikan kesimpulan terhadap hasil observasi

12. Refleksi hasil layanan bimbingan kelompok

Tahapan ini merupakan tahap merefleksi terhadap layanan yang telah diberikan berdasarkan dari hasil observasi terhadap prilaku/disiplin siswa baik pada awal jam pelajar selama proses pembelajaran dan akhir pelajaran. Data yang dibutuhkan dalam penelitian 
ini adalah data tentang perilaku disiplin siswa. Untuk memperoleh data yang akurat teknik pengumpulan data yang digunakan adalah Observasi. Observasi adalah adalah suatu teknik pengumpulan data, dimana peneliti melakukan pengamatan secara langsung ke objek penelitian untuk melihat dari dekat kegiatan yang dilakukan (Riduwan, 2004 : 104).

Dalam PTK BK ini observasi yang dilakukan yaitu melakukan observasi terhadap terjadinya penyimpangan disiplin setelah siswa tersebut diberikan layanan bimbingan kelompok dalam jangka waktu tertentu. Instrumen pengumpulan data adalah berupa lembar observasi yang dipilih dan yang digunakan oleh peneliti dalam kegiatanya agar kegiatan tersebut menjadi sistematis dan dipermudah dengan adanya instrumen yang diartikan sebagai alat bantu dalam melakukan penelitian.

Dalam observasi yang digunakan ini terdiri dari dua penyataan yaitu pernyataan positif dan pernyataan negarati, masing-masing pernyataan tersebut terdiri dari beberapa pertayaan yang berkaitan dengan disiplin siswa dengan dua sekala yang digunakan dalam tiap pernyataan yaitu : ya dan tidak, dengan kreterian ya $=1$ dan tidak $=0$ bagi pernyataan posirif dan ya $=0$ dan tidak $=1$ bagi pernyataan negatif. Untuk mengetahui persentase perubahan perilaku berupa penurunan perilaku terhadap disiplin siswa dipantau dengan lembar observasi dan skor hasil observasi setelah layanan bimbingan kelompok dilaksanakan, maka akan dianalisis secara deskriptif yaitu analisis dengan membandingkan persentase yang dicapai sebelum dan sesudah diadakan tindakan. Instrument observasi yang akan digunakan sebagai instrument penelitian.

Untuk melihat kriteria keberhasilan pada PTK BK ini dengan cara menganalisi hasil pengamatan setelah dilakukan bimbingan kelompok dengan menggunkan hasil persetnase, selanjutnya disimpulkan hasil pelaksanaan PTK BK ini berhasil atau tidak. Penentuan keberhasilan tersebut menggunakan kriteria diskriftif persentase, sebagai berikut:

Tabel 1. Kriteria Deskripsi Persentase

\begin{tabular}{lcl}
\hline No & Interval Persentase Skor & \multicolumn{1}{c}{ Kriteri } \\
\hline 1. & $84<\%<100$ & Sangat Tinggi (ST ) \\
2. & $68<\%<84$ & Tinggi ( T ) \\
3. & $52<\%<68$ & Sedang ( S ) \\
4. & $36<\%<52$ & Rendah ( R ) \\
5. & $20<\%<36$ & Sangat Rendah ( SR ) \\
\hline
\end{tabular}

Sumber: Tu'us (2004) 


\section{HASIL DAN PEMBAAHASAN}

\section{Hasil Penelitian}

Data siswa yang termasuk sering melangar disiplin sekolah adalah dari hasil absensis guru dan wawancara dengan guru mata pelajaran selama semester ganjil tahun pelajaran 2018/2019, maka terdapatlah 10 orang siswa yang diketahui bahwa menunjukan prilaku melanggar disiplin di sekolah. Tentunya hal semacam ini harus sesegera mungkin untuk diselesaikan, sebagai bagian terintegritas dari SMA Negeri 1 Maumere, peneliti (guru Bimbingan Konseling) merasa ikut bertanggung jawab untuk meminimalkan siswa yang melakukan perilaku melanggar disiplin di sekolah dan prilaku membolos.

Penelitian ini terdiri dari 3 siklus, yaitu pada bulan Februari dan April 2018. Dalam 1 kali siklus dilaksanakan 1 kali layanan Bimbingan Kelompok dan untuk mengetahui tingkat keberhasilan terhadap disiplin siswa dengan melakukan observasi terhadap ke-10 siswa tersebut. Pada siklus pertama diperoleh hasil observasi dari pelaksanaan dari Layanan Bimbingan Kelompok pada siswa yang mengalami masalah terhdapat disiplin dapat dilihat dari hasil obsevasi, sebagai barikut:

Tabel 2. Hasil Observasi pada Siklus 1 (Pernyataan Positif)

\begin{tabular}{lllll}
\hline \multicolumn{1}{c}{ NO } & $\begin{array}{c}\text { Kode } \\
\text { Siswa }\end{array}$ & \multicolumn{2}{c}{$\begin{array}{c}\text { Hasil } \\
\text { Observasi }\end{array}$} & \begin{tabular}{c} 
Rata \\
rata \\
\cline { 3 - 4 }
\end{tabular} \\
\cline { 3 - 4 } & & $\mathbf{7}$ & $\mathbf{1 2}$ & \multicolumn{1}{c}{26} \\
\hline 1 & AN & 23 & 26 & 24.5 \\
\hline 2 & AD & 25 & 28 & 26.5 \\
\hline 3 & BA & 27 & 30 & 28.5 \\
\hline 4 & BB & 29 & 35 & 32 \\
\hline 5 & MR & 25 & 45 & 35 \\
\hline 6 & NU & 28 & 45 & 36.5 \\
\hline 7 & TE & 33 & 45 & 39 \\
\hline 8 & SI & 34 & 45 & 39.5 \\
\hline 9 & YO & 31 & 48 & 39.5 \\
\hline 10 & YP & 22 & 49 & 35.5 \\
\hline Jumlah & & 277 & 396 & 340.5 \\
\hline
\end{tabular}

Berdasarkan pada tabel 2 dinyatakan bahwa pernyataaan positif siswa terhadap pelaksanaan disiplin disekolah belum memuaskan dari 2 kali dilakukan observasi, Jika dilihat dari hasil pelaksanan observasi pada tanggal 7 Maret dengan rata-rata $27.7 \%$ dan tanggal 12 Maret rata-rata 39.6\% dengan rata-rata keseluruhan adalah 34,05\%, Artinya dari ke 10 orang siswa masih sering melakukan pelanggaran terhadap disiplin di sekolah.

Tabel 3. Hasil Observasi pada Siklus I (pernyataan negatif) 


\begin{tabular}{|c|c|c|c|c|c|}
\hline \multirow{2}{*}{ NO } & \multirow{2}{*}{$\begin{array}{l}\text { Kode } \\
\text { Siswa }\end{array}$} & \multicolumn{2}{|c|}{ Hasit Observasi } & \multirow[b]{2}{*}{ Jumlah } & \multirow{2}{*}{$\begin{array}{l}\text { Rata } \\
\text { rata } \\
(\%)\end{array}$} \\
\hline & & 7 & 12 & & \\
\hline 1 & AN & 50 & 65 & 115 & 57,5 \\
\hline 2 & $\mathrm{AD}$ & 45 & 58 & 103 & 51,5 \\
\hline 3 & BA & 52 & 55 & 107 & 53,5 \\
\hline 4 & $\mathrm{BB}$ & 25 & 50 & 75 & 37,5 \\
\hline 5 & MR & 30 & 35 & 65 & 32,5 \\
\hline 6 & $\mathrm{NU}$ & 40 & 55 & 95 & 47,5 \\
\hline 7 & $\mathrm{TE}$ & 55 & 50 & 105 & 52,5 \\
\hline 8 & SI & 53 & 60 & 113 & 56,5 \\
\hline 9 & $\mathrm{YO}$ & 55 & 65 & 120 & 60 \\
\hline 10 & YP & 50 & 60 & 110 & 55 \\
\hline Jumlah & & 455 & 553 & 1008 & 504 \\
\hline
\end{tabular}

Berdasarkan tabel 3 dinyatakan bahwa pernyataaan negatif siswa terhadap pelaksanaan disiplin disekolah belum memuaskan dari 2 kali dilakukan observasi, jika dilihat dari hasil pelaksanan observasi pada tanggal 7 Maret dengan rata-rata 45,5\% dan tanggal 12 Maret rata-rata 55,3\% dengan rata-rata keseluruhan adalah 50,4\%.

Berdasarkan pada paparan diatas dapatlah dikatakan bahwa tingkat disiplin siswa kategori rendah pernyataan positif dan sedang pada yang menjadi penyebab permasalahan dan bagaimana cara mengatasinya. Tetapi pada kenyataannya hasil dari observasi menunjukan bahwa ke 10 siswa tersebut masih saja melakukan beberapa pelanggran terhadap disiplin di sekolah, maka pada akhirnya peneliti mengadakan siklus ke-2 yaitu layanan bimbingan kelompok lanjutan.

Perecanaan pada siklus kedua dirancang hasil refleksi pada sisklus pertama. Pelaksanaan pada siklus ke-2 pada layanan bimbingan kelompok dilaksanakan pada tanggal 3 April 2018, guru Bimbingan Konseling melakukan layanan bimbingan kelompok sesuai dengan tahap-tahap mulai dari penjelasan tentang maksud dan tujuan layanan konseling kelompok, pengakraban anggota. Pada waktu pelaksanaan layanan bimbingan kelompok guru Bimbingan Konseling mengajak setiap anggota kelompok untuk pengungkapan masalah secara bebas tetapi masih berkaitan dengan disiplin, kemudian guru Bimbingan Konseling sebagai ketua kelompok mengajak anggotanya untuk menyepakati masalah mana yang dibahas lebih lanjut bersama anggota kelompok. Akhir dari layanan tersebut dianggota kelompok tersebut dapat memahami apa yang menjadi kesalahannya dan berjanji untuk tidak akan melanggar disipilin lagi.

Setelah dilakukan layanan bimbingan kelompok maka peneliti melakukan observasi terhadap ke 10 siswa tersebut yang dilaksanakan selama 2 hari secara acak 
dibantu teman sejawat atau guru SMA Negeri 1 Maumere adapun tujuan dilakukan observasi untuk mengathui apakah terjadi perubahan prilaku pada diri siswa setelah diberikan layanan bimbingan kelompok.

Hasil dari pelaksanaan dari Layanan Bimbingan Kelompok pada siswa yang mengalami masalah terhdapat disiplin dapat dilihat dari hasil obsevasi, sebagai berikut.

Tabel 4. Hasil Observasi pada Siklus 2 (pernyataan positif)

\begin{tabular}{|c|c|c|c|c|c|}
\hline \multirow{2}{*}{ NO } & \multirow{2}{*}{ Kode Siswa } & \multicolumn{2}{|c|}{ Hasil Observasi } & \multirow[b]{2}{*}{ Jumlah } & \multirow{2}{*}{$\begin{array}{l}\text { Rata } \\
\text { rata } \\
(\%)\end{array}$} \\
\hline & & 17 & 23 & & \\
\hline 1 & AN & 80 & 83 & 163 & 81,5 \\
\hline 2 & $\mathrm{AD}$ & 88 & 85 & 173 & 86,5 \\
\hline 3 & $\mathrm{BA}$ & 89 & 91 & 180 & 90 \\
\hline 4 & $\mathrm{BB}$ & 80 & 78 & 158 & 79 \\
\hline 5 & MR & 87 & 90 & 177 & 88,5 \\
\hline 6 & $\mathrm{NU}$ & 86 & 93 & 179 & 89,5 \\
\hline 7 & $\mathrm{TE}$ & 87 & 96 & 183 & 91,5 \\
\hline 8 & SI & 88 & 98 & 186 & 93 \\
\hline 9 & $\mathrm{YO}$ & 86 & 87 & 173 & 86,5 \\
\hline 10 & YP & 85 & 86 & 171 & 85,5 \\
\hline Jumlah & & 856 & 887 & 1743 & 871,5 \\
\hline
\end{tabular}

Berdasarkan pada tabel 4 dinyatakan bahwa pernyataaan positif siswa terhadap pelaksanaan disiplin disekolah sudah memuaskan dari 2 kali dilakukan observasi terhadap siswa yang telah diberikan layanan bimbingan kelompok, jika dilihat dari hasil pelaksanan observasi pada tanggal 7 April dengan rata-rata 87,4\% dan tanggal 23 April rata-rata $86 \%$ dengan rata-rata keseluruhan adalah 86,7\%, dengan kategori tinggu Artinya dari ke 7 orang siswa tidak melakukan pelanggaran terhadap disiplin disekolah.

Tabel 5. Hasil Observasi Siklus 2 (Pernyataan Negatif)

\begin{tabular}{ccccrc}
\hline \multirow{2}{*}{ NO } & Kode & \multicolumn{2}{c}{ Hasil Observasi } & & $\begin{array}{c}\text { Rata } \\
\text { Siswa }\end{array}$ \\
\cline { 3 - 4 } & 17 & 23 & Jumlah & $\begin{array}{c}\text { rata } \\
(\%)\end{array}$ \\
\hline
\end{tabular}




\begin{tabular}{rrrrrr}
1 & AN & 85 & 85 & 170 & 85 \\
\hline 2 & AD & 95 & 80 & 175 & 87,5 \\
\hline 3 & BA & 85 & 80 & 165 & 82,5 \\
\hline 4 & BB & 92 & 85 & 177 & 88,5 \\
\hline 5 & MR & 88 & 85 & 173 & 86,5 \\
\hline 6 & NU & 85 & 90 & 175 & 87,5 \\
\hline 7 & TE & 89 & 90 & 177 & 88,5 \\
\hline 8 & SI & 85 & 90 & 175 & 87,5 \\
\hline 9 & YO & 85 & 88 & 173 & 86,5 \\
\hline 10 & YP & 85 & 89 & 174 & 87 \\
\hline Jumlah & & 860 & 874 & 1734 & 867 \\
\hline
\end{tabular}

Berdasarkan tabel 5 dinyatakan bahwa pernyataaan negatif siswa terhadap pelaksanaan disiplin disekolah kategori tinggi, dari 2 kali dilakukan observasi, Jika dilihat dari hasil pelaksanan observasi pada tanggal 17 April dengan rata-rata 86\% dan tanggal 23 April dengan rata-rata 87,4\% dengan rata-rata keseluruhan adalah $86,7 \%$, berdasarkan pada rata- rata dari hasil observasi dan proses layanan konseling kelompok pada siklus ke 2 secara umum mengalami peningkatan yang signitifkan.

Berdasarkan analisis dari hasil observasi yang telah dilakukan baik yang telah terjadwal maupun yang tidak terjadwal pada setiap siklus, maka dapat diketahui persentase hasil yang telah diperoleh tersebut akan dipaparkan pada tabel dibawah ini

Tabel 6. Data Hasil Observasi pada Siklus 1 dan Siklus 2

\begin{tabular}{lrrllll}
\hline \multirow{2}{*}{ No } & Siklus & \multicolumn{4}{c}{ Persentase } \\
\cline { 2 - 6 } & \multicolumn{2}{c}{$\begin{array}{l}\text { Pernyataan } \\
\text { Positif }\end{array}$} & Kategori & $\begin{array}{l}\text { Pernyataan } \\
\text { Negatif }\end{array}$ & Kategori \\
\hline 1 & 1 & 34,5 & rendah & 50,4 & sedang \\
\hline 2 & 2 & 87,15 & Tinggi & 86,7 & Tinggi \\
\hline
\end{tabular}

Berdasarkan tabel 6 di atas dapat di katakan bahwa terjadinya peningkatan perubahan disiplin siswa pada setiap siklusnya. Angka-angka tersebut diperoleh dari penilaian observer yang memantau/mengamati terjadinya prilaku-prilaku yang menyimpang (kesesuaian dengan instrumen penelitian) yang dilakukan siswa baik pada awal jam pelajaran pertengan maupun diakhir jam pelajaran, perbaikan pada setiap siklus yang dilakukan oleh peneliti selaku guru BK di SMA Negeri 1 Maumere dengan memberikan saran dan masukan pada saat proses layanan bimbingan kelompok.

\section{Pembahasan}

Berdasarkan siklus di atas dapat diketahui bahwa terjadinya peningkatan / perbaikan setiap siklus terhadap disiplin siswa di sekolah baik pada awal jam pelajaran 
kelas XI IPS SMA Negeri 1 Maumere selama dua siklus penelitian tindakan kelas yang dilakukan oleh peneliti, maka dapat diketahui lebih jelas yang menunjukan bahwa adanya peningkatan itu terjadi. Hal tersebut diperkuat dari hasil penelitiannya Syarif, Dahlan \& Andriyanto (2019) yang menyimpulkan konseling kelompok teknik percontohan dapat digunakan untuk meningkatkan kedisiplinan siswa kelas X SMA Negeri 6 Bandar Lampung Tahun Pelajaran 2017/2018. Selain itu menurut Buhani (2017) pelaksanaan pelayanan bimbingan kelompok menunjukkan bahwa adanya peningkatan skor disiplin siswa. Peningkatan itu didasarkan atas hasil penelitian dari pemantauan observasi awal sebelum tindakan dengan setelah tindakan kedua siklus terjadi peningkatan rata-rata skor disiplin untuk siklus I 18,49\% dan siklus II 19,41\%. Sedangkan untuk 8 siswa yang skor disiplinnya dibawah ratarata (60) mengalami peningkatan sangat tinggi yaitu 80,52\%. Dengan demikian dapat disimpulkan bahwa implementasi layanan bimbingan kelompok dapat meningkatkan kedisiplinan siswa kelas VIII SMP PGRI Banyuwangi tahun pelajaran 2016/2017 (Buhani, 2017). Selanjutnya selaras dengan hasil penelitiannya Suwignyo \& Nusantoro (2015) yang menyimpulkan ada pengaruh yang signifikan dari layanan bimbingan kelompok terhadap kedisiplinan belajar pada siswa kelas VIII.D SMP Negeri 41 Gunungpati Semarang Tahun Ajaran 2014/2015.

\section{SIMPULAN}

Upaya meningkatan disiplin siswa melalui layanan bimbingan kelompok pada siswa kelas XI IPS SMA Negeri 1 Maumere mengalami peningktan pada setiap siklusnya Pada peryataan positif silkus I 34,5\% (kategori rendah) mengalami peningkatan siklus II 87,15\% Pada pernyataan negative siklus I 50,4\% (kategori sedang), mengalami peningkatan pada siklus III 86,7 \% (kategori sangat tinggi). Dengan demikian dapat disimpulkan: pertama penggunaan layanan bimbingan kelompok sangat efektif dalam upaya meningkatkan disiplin siswa yang berdampak pada peningkatan tingkat kehadiran siswa. Kedua tingkat disiplin siswa pada awal pelajaran/ masuk kelas, selama proses pembelajaran dan akhiri dari pembelajaran (pulang sesuai jadwal) pada kelas XI IPS SMA Negeri 1 Maumere sangat tinggi. Ketiga perilaku disiplin di dalam kelas dan disiplin menepati jadwal terus meningkat dari siklus 1 sampai siklus

\section{DAFTAR PUSTAKA}


Ariananda, E. S., Hasan, S., \& Rakhman, M. (2014). Pengaruh kedisiplinan siswa disekolah terhadap prestasi belajar siswa teknik pendingin. Journal of Mechanical Engineering Education, 1(2), 233-238.

Arikunto, Suharismi. 1990. Peraturan dan Tata Tertib. Jakarta: Reneika Cipta

Buhani, B. (2017). Implementasi Bimbingan Kelompok Dalam Meningkatkan Kedisiplinan Siswa Kelas VIII SMP PGRI Banyuwangi Tahun Pelajaran 2016/2017. Jurnal Edukasi, 4(2), 31-37.

Haryono, S. (2016). Pengaruh Kedisiplinan Siswa Dan Motivasi Belajar Terhadap Prestasi Belajar Siswa Pada Mata Pelajaran Ekonomi. Faktor Jurnal Ilmiah Kependidikan Vol. 3 No. 3 November 2016, hal 261-274

Nurdin, S. (2005). Guru Profesional \& Implementasi Kurikulum. Jakarta: Quantum Teaching.

Prayitno, E. A. (1995). Layanan Bimbingan dan Konseling Kelompok (Dasar dan Profil). Jakarta: Ghalia Indonesia.

Prayitno, E. A. (2001). Buku Panduan Pelayanan Bimbingan dan Konseling Berbasis Kompetensi. Padang: P4T IKIP Padang.

Prayitno, E. A. (2004). Dasar-dasar Bimbingan dan Konseling. Jakarta: Rineka Cipta.

Rohman, F. (2018). Peran Pendidik dalam Pembinaan Disiplin Siswa di Sekolah/Madrasah. Ihya al-Arabiyah: Jurnal Pendidikan Bahasa dan Sastra Arab, 4(1).

Suwignyo, H., \& Nusantoro, E. (2015). Pengaruh Layanan Bimbingan Kelompok Terhadap Kedisiplinan Belajar pada Siswa Kelas VIII D. Indonesian Journal of Guidance and Counseling: Theory and Application, 4(3).

Syarif, A, Dahlan, S, Andriyanto, E.E. (2019). Peningkatan Kedisiplinan di Sekolah Menggunakan Konseling Kelompok Teknik Percontohan. Alibkin: Jurnal Bimbingan Konseling, Vol 7, No 1 (2019)

Tiring. S. S. N. D. (2019). Perbedaan pendekatan scince, Environment, Technology and Society dan Kontxtual Teaching and Learning Terhadap Hasil Belajar Kognitif pada Materi Asam Basa Kelas X MIA SMA Negeri 1 Maumere. Jurnal Serambi PTK. VOL. VI. No. 3. ISSN. 2355-9535

Tu'u. (1994). Supervise Pendidikan Dalam Rangka Perbaikan Situasi Belajar. Jakarta: Bina Aksara,

Tu’u. (2004). Peran Disiplin Pada Perilaku dan Prestasi Siswa. Jakarta: Grasindo

Wahyuni, D., Wati, M., \& Ely, R. (2016). Hubungan Kedisiplinan terhadap Hasil Belajar Siswa Kelas V di SD Negeri 10 Banda Aceh. Jurnal Ilmiah Mahasiswa Pendidikan Guru Sekolah Dasar, 1(1). 
